\title{
Violența în familie, o nouă țintă a politicii penale populiste
}

\author{
Prof. univ. dr. Valerian Cioclei \\ Facultatea de Drept, Universitatea din București \\ Avocat, partener of counsel ZRVP
}

Rezumat: Actul normativ criticat în prezentul articol se inscrie în genul de politică penală populistă, având ca obiect modificarea art. 199 C.pen. - Violența în familie. Prima parte face o "radiografie” a diletantismului juridic ce rezultă din expunerea de motive ce a stat la baza Legii. A doua parte se axează pe evidențierea caracterului nociv al modificării legislative analizate.

Cuvinte cheie: violența în familie, membru de familie, plângere prealabilă, impăcarea, lovirea sau alte violențe, vătămarea corporală din culpă.

\section{Domestic violence, a new target of the populist criminal policy}

Abstract: The law criticized in this article can be categorised in the area of populist criminal policy, having as object the modification of art. 199 Criminal Code - Domestic violence. The first part contains an "x-ray" of legal dilettantism resulting from the reasoning of the Law. The second part focuses on highlighting the harmful nature of the analysed legislative change.

Key words: domestic violence, family member, prior complaint, reconciliation, hitting or other violence, culpable bodily harm.

Nici nu s-a „uscat bine cerneala" articolului prin care atrăgeam atenția asupra pericolului politicii penale populiste (3P, un ,virus" reactivat, care amenință sănătatea justiției penale ${ }^{1}$ ) că, iată, sunt obligat să semnalez un nou caz „flagrant”, ce se înscrie în același gen de politică. La fel ca proiectele de lege la care $\mathrm{m}$-am referit în articolul menționat anterior, proiecte ce vizau violențele sexuale asupra minorilor, noul act normativ are ca, ,tintă” tot un subiect sensibil, care atrage în mod natural interesul opiniei publice, respectiv violența în familie. Astfel, aflăm din mass media că printr-o modificare a Codului penal s-a dat lovitura de grație violenței în familie. Curios din fire, am vrut să verific „intensitatea loviturii” (I) și „,consecințele” acesteia (II).

\section{Intensitatea loviturii}

La data de 13.10.2020, Camera Deputaţilor a adoptat (în unanimitate) un proiect de lege (PL-x nr. 103/2018), care prevede modificarea art. 199 alin. (2)

\footnotetext{
${ }^{1}$ Disponibil la: https://www.bizlawyer.ro/stiri/interviuri-opinii/3p-un-virus-reactivat-care-ameninta-sanatateajustitiei-penale
} 
C.pen. La data de 19.10.2020 Legea a fost trimisă spre promulgare Președintelui României².

În prezent, articolul 199 din Codul penal (Violența în familie) are următorul conținut: „(1) Dacă faptele prevăzute în art. 188, art. 189 și art. 193-195 sunt săvârşite asupra unui membru de familie, maximul special al pedepsei prevăzute de lege se majorează cu o pătrime. (2) În cazul infracțiunilor prevăzute în art. 193 și art. 196 săvârșite asupra unui membru de familie, acțiunea penală poate fi pusă în mișcare și din oficiu. Împăcarea înlătură răspunderea penală”.

Legea de modificare, simplă, dar și simplistă, după cum se va vedea, suprimă pur și simplu ultima propoziție de la alin. (2), care prevede că: „Împăcarea înlătură răspunderea penală”.

Pentru a afla care a fost „,voința legiuitorului” am consultat, firește, Expunerea de motive a Proiectului de Lege. Am lăsat de o parte greșelile de ortografie și de exprimare pe care le poate observa cu ușurință oricine lecturează documentul $^{3}$, fiind copleșit de ,profunzimea” substratului filozofic al modificării, sintetizat în următoarea frază: „De aceea, pentru a proteja mai bine victimele violenței domestice, care cel mai adesea sunt femei, este necesară atât schimbarea de mentalitate tributară unor formule tradiţionale de genul „bătaia e ruptă din rai” ori „dacă nu e gelos și nu te bate, nu te iubește cu adevărat”, cât și acele portițe din lege care pot permite perpetuarea unei stări de violență ori care să îl ajute pe agresor să scape de răspunderea penală pentru faptele sale"4. Problema „portițelor” revine și în argumentaţia „pur juridică” pe care o voi reda în continuare: „Legislația românească menține însă o portiţă prin care autorul faptelor penale poate să fie complet exonerat de răspunderea penală pentru faptele sale întrucât Art. 199 din Codul Penal prevede că ,împăcarea înlătură răspunderea penală". Or, adesea, asupra victimei pot fi exercitate presiuni pentru a o face să își retragă plângerea, ceea ce pe de o parte îi permite agresorului să scape de răspundere penală, iar pe de alta, reprezintă o invitație de a continua să exercite acte de violență și să își intimideze victima astfel încât aceasta să renunțe să mai depună plângere ori să și-o retragă pe cea înaintată deja. Dacă legea nu este fermă în a-i descuraja ori pedepsi, de la caz la caz, pe agresori, ea riscă să nu fie un instrument adecvat pentru a apăra victimele. Posibilitatea prevăzută acum de Codul Penal ca agresorul să se împace cu victima menține riscuri majore pentru aceasta din urmă de a fi în continuare abuzată și agresată, dar expune și alte persoane riscurilor de a cădea victime unui agresor care știe că are la îndemână și portița împăcării”’5.

Diletantismul juridic al argumentelor de mai sus este evidențiat de confuzia care se face între cele două instituții: cea a plângerii prealabile (art. 157 și art. 158 C.pen.) și cea a împăcării (art. 159 C.pen.). Presiunile care se fac asupra victimelor

\footnotetext{
${ }^{2}$ Disponibil la: http://www.cdep.ro/pls/proiecte/upl_pck2015.proiect?cam=2\&idp=16428

${ }^{3}$ Disponibil la: http://www.cdep.ro/proiecte/2018/100/00/3/em120.pdf

${ }^{4}$ Idem.

${ }^{5}$ Idem.
} 
pentru a nu depune plângere prealabilă ori pentru a o retrage reprezintă o realitate care nu poate fi combătută prin „,imposibilitatea împăcării”, deoarece instituția împăcării intervine, dacă legea o prevede în mod expres, doar când acțiunea penală a fost pusă în mișcare din oficiu (nu la plângere prealabilă). Confuzia amintită și faptul că „propunătorii” nu au avut habar de consecințele modificării rezultă și din configuraţia iniţială a Proiectului care prevedea că: „Împăcarea nu înlătură răspunderea penală”. Consiliul legislativ, deși a avizat favorabil propunerea de modificare (!?!) a atras atenția (jenat aș zice eu) că, „expresia împăcarea nu înlătură răspunderea penală este superfluă"6, având în vedere dispozițiile art. 159 C.pen. (conform cărora împăcarea poate interveni dacă legea o prevede in mod expres). Ca atare, în final s-a ales soluția suprimării textului, așa cum arătam mai sus.

În acelaşi timp se observă o fractură logică între motivarea modificării și consecințele acesteia. După cum s-a putut observa, în expunerea de motive se face referire la „bătaie”, la „,agresor”, la „exercitare de violenţe”, la „,intimidarea victimei" etc. Toate aceste expresii indică fapte comise cu intenție, cu privire la care ar fi incidente doar dispozițiile art. 193 Cod penal, lovirea sau alte violențe. Or, modificarea are consecințe și asupra art. $196 \mathrm{Cod}$ penal, vătămarea corporală din culpă (spre exemplu un accident de circulație), ceea ce nu pare să aibă legătură cu motivele din expunere și cu imaginea mai degrabă ,jurnalistică”, pe care „propunătorii” par să o aibă asupra violenţei în familie.

Modul în care este redactată Expunerea de motive, precum și propunerea de modificare a art. 199 C.pen., în sine, sugerează că inițiatorii proiectului nu au făcut nici măcar un minim efort de a se documenta asupra subiectului. Ca și alți autori, am explicat şi eu, în alt context, sensul art. 199 alin. (2), precum și diferența dintre retragerea plângerii și împăcare, arătând următoarele: „În cazul infracțiunilor pentru care, în condiții normale, acțiunea penală se pune în mișcare la plângerea prealabilă a persoanei vătămate, respectiv lovirea sau alte violențe și vătămarea corporală din culpă, în mod excepțional, în cazul în care victima este un membru de familie, acțiunea penală poate fi pusă în mișcare și din oficiu. Această dispoziție (cu corespondență și în legea veche) are rolul de a oferi o protecție suplimentară victimelor, având în vedere poziția lor de vulnerabilitate și uneori chiar de dependenţă față de agresor, poziție ce le-ar putea împiedica, în unele cazuri, să depună plângere. Chiar și în aceste situații, totuși, împăcarea înlătură răspunderea penală [art. 199 alin. (2)]. Atenție însă: împăcarea operează exclusiv în cazul punerii în mișcare a acțiunii penale din oficiu. Dacă acțiunea penală a fost pusă în mișcare în condiții normale, prin plângere prealabilă, ,încetarea procesului penal poate fi dispusă numai ca efect al retragerii plângerii prealabile și nu ca efect al împăcării"’".

\footnotetext{
${ }^{6}$ Disponibil la: http://www.cdep.ro/proiecte/2018/100/00/3/c1120.pdf

${ }^{7}$ V. Cioclei, Drept penal partea specială. Infracțiuni contra persoanei și infracțiuni contra patrimoniului. Ed. CH. Beck, 2020, p. 97, cu referire la: I.C.C.J., Completul pentru soluționarea recursului în interesul legii (RIL), Decizia nr. 11/2019 (M.Of. nr. 477 din 12 iunie 2019).
} 
Prin urmare, indiferent ce s-a urmărit prin legea de modificare, rezultatul este următorul: pentru infracțiunile prevăzute de art. 193 C.pen. (lovirea sau alte violențe) și art. 196 C.pen. (vătămarea corporală), când victima este un membru de familie, dacă acțiunea penală este pusă în mișcare din oficiu, răspunderea penală nu mai poate fi înlăturată prin împăcare.

\section{Consecințele}

Consider că această modificare este nechibzuită, deoarece creează o dublă discriminare. Prima are un caracter general, prin raportare la subiecții celor două infracțiuni, în ipoteza în care nu au între ei calitatea de membru de familie și cărora li se acordă beneficiul dispoziției asupra acțiunii penale, prin instituția plângerii prealabile. Cu alte cuvinte, pentru a fi înțeles și de „propunători”, dacă victima unei loviri sau a unei vătămări corporale din culpă, nu este membru de familie în raport cu făptuitorul, aceasta beneficiază din plin de dreptul de dispoziție asupra acțiunii penale: ea poate să nu depună plângere prealabilă împotriva făptuitorului sau, dacă o depune, poate să se răzgândească și să o retragă, în condițiile legii (art. 158 C.pen.). În ambele cazuri, răspunderea penală a făptuitorului este înlăturată. Dacă victima este membru de familie, dreptul de dispoziție îi este ,anulat” deoarece, în cazul în care nu dorește să depună plângere prealabilă împotriva făptuitorului (fiul, spre exemplu), există posibilitatea ca acțiunea penală să fie pusă în mișcare din oficiu, contra voinței sale, și, în condițiile modificării, nu mai are posibilitatea să împiedice tragerea la răspundere penală a făptuitorului, prin împăcare. Nu văd de ce, un cetățean ar putea să-și exercite ,dreptul de clemență” cu privire la un „străin”, iar un alt cetățean nu ar putea să-și exercite același drept cu privire la un „membru de familie”. Nu cred că un astfel de tratament „diferențiat” poate fi considerat compatibil cu art. 16 alin. (1) din Constituția României, care stabilește că: „Cetățenii sunt egali în fața legii și autorităţilor publice, fără privilegii și fără discriminări”.

A doua discriminare are un caracter special, prin raportare la subiecții celor două infracțiuni care au calitatea de membru de familie, în ipoteza în care victima a depus plângere prealabilă și pentru care subzistă beneficiul dispoziției asupra acțiunii penale, deoarece poate să-şi retragă plângerea. Nu există nicio logică în baza căreia victima care a depus plângere prealabilă să aibă dreptul de a dispune de acțiunea penală prin retragerea acesteia, în timp ce victima care (nici măcar) nu a depus plângere să nu poată beneficia de același drept. $\mathrm{Cu}$ alte cuvinte, ca să mă fac înțeles de aceiași ,,propunători”, dacă victima, membru de familie, ,,apucă” să depună plângere prealabilă pentru una din cele două infracțiuni menționate, ea poate să și-o retragă, ceea ce va avea ca efect înlăturarea răspunderii penale a făptuitorului, iar organul de urmărire penală nu poate face altceva decât să constate această situație. În acest sens, în doctrină, cu referire la soluții din practica 
judiciară, s-a arătat că: ,dacă organele de urmărire penală sunt sesizate cu o plângere prealabilă valabilă, acestea nu vor mai putea porni din oficiu acțiunea penală, manifestarea de voință a persoanei vătămate având prioritate" 8 . În schimb, dacă victima, membru de familie, nu este suficient de ,iute de pix” și nu depune plângere prealabilă, iar organul de urmărire penală pune în mișcare acțiunea penală din oficiu, făptuitorul va putea fi tras la răspundere penală, chiar împotriva voinței victimei. Diferența de tratament este, și în acest caz, total nejustificată.

Modificarea art. 199 alin. (2) C.pen., prin înlăturarea posibilităţii de împăcare, este nu numai discriminatorie, dar și lipsită de logică. Această lipsă de logică este și mai evidentă dacă ne raportăm exclusiv la vătămarea din culpă (art. 196 C.pen.). Astfel, să luăm ca exemplu ipoteza unui accident auto, în care victimă este pasagerul din dreapta, soțul conducătoarei auto responsabilă de accident. $\mathrm{Nu}$ întâmplător am ales ca victima să fie o persoană de sex masculin ci, pentru a atrage atenția că, din punct de vedere penal (și nu jurnalistic), art. 199 alin. (2) C.pen. nu se referă exclusiv la persoanele de sex feminin. Pentru ,reducere la absurd”, putem da „o tușă mai groasă” speței, imaginându-ne că soțul este cel care o roagă pe soție să conducă în viteză, peste limita legală, pentru a nu întârzia la un eveniment la care el este invitat. În condiţiile unui carosabil alunecos, soția pierde controlul volanului și intră într-un copac de pe marginea șoselei. În urma accidentului, ambii soți suferă vătămări corporale ce se încadrează în cele prevăzute la art. 194 alin. (1) Cod penal (spre exemplu infirmitate, sau leziuni pentru care au fost necesare mai mult de 90 de zile de îngrijiri medicale). Deși, în condițiile date, este evident că soțul nu are niciun interes să-și vadă soția (rămasă infirmă), trasă la răspundere penală, în baza art. 196 Cod penal, el nu va avea posibilitatea să împiedice acest lucru, dacă acțiunea penală va fi pusă în mișcare din oficiu. Pentru a preîntâmpina, totuși, un astfel de deznodământ, soțul, sfătuit de un avocat abil, ar trebui să acționeze ,înaintea” organelor de urmărire penală și să depună plângere prealabilă împotriva soției, pentru a putea ulterior să-și retragă plângerea. Reamintesc faptul că un astfel de ,artificiu” nu ar fi necesar, dacă la volan s-ar fi aflat o persoană cu care victima nu ar fi avut o legătură de familie, deoarece ar fi putut împiedica tragerea la răspundere penală a acesteia prin „simpla” nedepunere a unei plângeri prealabile. Pare absurd? Nu pare, chiar este...

Rezumând, modificarea propusă ar avea un impact punctual, o sferă de aplicare restrânsă la situațiile în care organele de urmărire penală ar fi „mai rapide" decât victimele și ar pune în mișcare acțiunea penală, înainte ca acestea să depună o plângere prealabilă. În această „nișă”, decizia ar aparține organului de urmărire penală care poate pune sau nu în mișcare acțiunea penală în funcție de criterii aleatorii, care riscă să nu coincidă totdeauna cu interesele victimei. Din această cauză se vor isca multiple controverse. Spre exemplu, ar fi discutabil dacă,

\footnotetext{
${ }^{8}$ I. Nedelcu, în G. Bodoroncea, V. Cioclei, I. Kuglai, L.V. Lefterache, T. Manea, I. Nedelcu, F.M. Vasile, Codul penal. Comentariu pe articole, ed. 2, p. 459, apud C. Mitrache, Comentariul 17, în G. Antoniu, C. Bulai (coord.), Practica judiciară penală. Partea generală, Ed. Academiei Române, București, 1990, p. 242.
} 
după punerea în mișcare a acțiunii penale din oficiu, victima, aflată încă în termenul legal pentru depunerea plângerii prealabile, ar mai putea uza sau nu de acest drept și de cel corelativ, de a retrage respectiva plângere. În acest sens ar putea fi invocat principiul menționat mai sus, conform căruia „manifestarea de voință a părții vătămate ar avea prioritate". În plus, ar putea fi invocate excepții de neconstituționalitate, în baza discriminărilor evocate anterior.

Posibilitatea punerii în mișcare din oficiu a acțiunii penale, în cazul art. 199 alin. (2), a fost gândită de legiuitor ca o protecție suplimentară pentru victimele violenței în familie, din rațiunile pe care le-am precizat mai sus. O astfel de protecție nu poate fi însă oferită „cu sila”, prin nesocotirea voinței victimelor și prin discriminarea acestora în raport cu alți cetățeni. De aceea, posibilitatea împăcării trebuie să rămână un ,,instrument” în mâna victimei.

În procesul legislativ, acest Proiect de modificare a Codului penal, nu a trezit nicio „suspiciune”, nicio ,îndoială”. Problemele semnalate de mine mai sus pot fi greșite, nu dețin „monopolul științei Dreptului penal”, dar sunt probleme. Acestea, sau altele de acelaşi gen, trebuiau să fie discutate şi clarificate. $\mathrm{Nu}$ a fost aşa. Ca și Proiectele de lege privind unele modificări ale Codului penal la care m-am referit în articolul semnalat mai sus, și acest Proiect a trecut de Senat prin ceea ce am numit „procedura indolenței parlamentare” adică prin depășirea termenului de adoptare prevăzută de art. 75 alin. (2) teza a treia din Constituția României. Mai mult, la Camera Deputaţilor, Proiectul a repurtat o „victorie” absolută: 255 voturi pentru, zero voturi împotrivă, zero abțineri - Unanimitate. Cum altfel? Nu luptă toată lumea împotriva violenței domestice? Vă văd „,colegii voștri academicienii", cum ar fi spus un personaj de tristă amintire sau, mai pe românește, vă văd „colegii” voștri alegătorii...

În concluzie, modificarea analizată este foarte departe de „,nobilul țel” de a „proteja mai bine victimele violenței domestice”, proclamat în Expunerea de motive a Proiectului de Lege și „,trâmbiţat” în media după adoptarea acestuia. În realitate, ne aflăm din nou în fața unui exemplu de politică penală populistă ce nu poate avea decât efecte nocive.

La momentul la care am redactat acest comentariu, legea de modificare nu fusese încă promulgată. Dacă acest lucru se va întâmpla, consider că va fí o gravă eroare, din considerentele expuse pe scurt anterior.

21.10.2020

Materialul a fost publicat în revista online a Facultății de Drept, $\underline{\text { AUBD-Forum }}$ Juridic nr. 3/2020. 